\title{
Measurement in financial statement: Retrospection and prospects in the chaotic environment
}

\author{
Svitlana Kuznetsova, Inna Tyvanyuk \\ Department of International Finance and Banking, Alfred Nobel University, Dnipropetrovs'k, Ukraine
}

Email address:

kuznet@meta.ua (S. Kuznetsova), tuvanyuk@ukr.net (I. Tyvanyuk)

\section{To cite this article:}

Svitlana Kuznetsova, Inna Tyvanyuk. Measurement in Financial Statement: Retrospection and Prospects in the Chaotic Environment. Journal of Finance and Accounting. Special Issue: Synergy of Accounting, Finance and Management in Chaotic Environment.

Vol. 2, No. 6-1, 2014, pp. 13-20. doi: 10.11648/j.jfa.s.2014020601.13

\begin{abstract}
Transformation of approaches to using different measurements in closing financial statements has been analyzed in this article. Evolution of the term "fair value" has also been systematized; fair value measurement development has been investigated in the international environment. Normative regulation to using measurements on fair value in Ukraine has been presented. Algorithm for choosing the form of accounting using fair value in the context of chaotic environment has been proposed.
\end{abstract}

Keywords: Fair Value, Financial Statement, IFRS, US GAAP, Financial Statement Measurement

\section{Introduction}

Integration and globalization of economical processes in the global community have determined the necessity of formation of united conceptual grounds of providing accounting information of general purpose, which is introduced as financial accounting statement. External character of such statement stipulates its formation with the aim of fulfilling needs of those users, who cannot demand the statements formed considering their particular informational needs. A widespread practice is uniting of the business by purchasing or selling companies.

That is why information should be provided in financial accounting statement about purchasing, selling and holdings of securities, in the capital of an enterprise participation, management quality estimation, enterprise ability to fulfill commitments timely, provision of company commitments estimation, defining the sum of distributable dividends, enterprise activities and other managerial decisions regulation.

Ukrainian wish to become a full partner in the global society, on particular to obtain the status of a member of World Trade Organization, determines the necessity to consider correspondent international practice on the process of the country's normative provision of accomplishment of financial statement formation.

Today Ukraine has been experiencing a number of economic transformations; the reforms are actively conducted such as political, economic and social ones. On the summit in Brussels on 27 June 2014, Ukraine and European Union have signed the agreement about the association and free trade.

For business, it should provide new opportunities to extend selling their goods and services in EU as well as attract foreign investors. Having estimated and analyzed the conditions of the agreement about the association, a lot of experts-analysts believe that in the nearest future the necessity of implementation about 350 various legislative documents of EU into Ukrainian law by the Parliament of Ukraine will raise. These laws are also related to euro standards of accounting and audit.

Clear, understandable, available and credible financial statement makes an enterprise competitive and attractive on the investment market. Increasing volumes of foreign investments into Ukraine, first of all, depends on ability of Ukrainian companies to provide partners' trust and external financing through the actions for implementation of the efficient system of corporate management. [3].

On the other hand, it is reasonable to explore the directions of improvement of normative provision of financial accounting statement accomplishment in the context of informational support of its users for companies' management.

Using accounting information which is provided in financial statements in the process of analysis allows revealing major trends in the company development, mistakes in 
management and cases of abuse.

Moreover, financial statements provides the system of management of target figures of the company's development efficiency by comparison with correspondent figures of competitors or partners of the enterprise given in their financial statements and available for general use. Financial accounting statement figures are advisable to be used for production of particular target of work, estimation of management staff work, determination of company's development perspectives.

Production of financial statements correspondent to such requirements is complicated with instability of the external economic environment, presence of global financial crisis consequences, and influence of economic and political problems inside the state. Accounting is the major source of information in production of financial statements; therefore, one of important issues of accounting is to organize the enterprise's process of collection, registration, accumulation and reflection of the information about financial conditions of the company in the statements, which would be able to provide the users with the information about enterprise's market value.

In terms of chaotic economic environment, usage of fair value in the quality of measurement will allow completion of the basic function of accounting - informational support of users, because in the aspect of information credibility, historic value is not always optimal. For example, in measurement of long-term assets in terms of inflation their nominal values will seriously differ from the real one.

\section{Literature Review of the Theories of Property and Companies Measurement}

It is additionally rational to use this statement for the managers of a company in creation of convenient patterns applied in the process of financial planning. As underlined Evi Bodie and Robert K. Merton, people, responsible for financial decisions are provided with the absolute most information that interests them about the results of the economic activities of different companies from the standard financial statements published in annual and quarterly reports. [4, p. 110]. Therefore, one of the undisputable advantages of financial statement usage is provision of the opportunity to compare statement figures for particular periods.

Barton J. and Palmer R. state that collection and provision of accounting information (in the context of financial statement) is the social process in development of communication of economic ways of a company's development. This communication should be considered not only in terms of a particular company but also in the context of international communicational development of enterprises.

Therefore, despite the fact that information provided in the financial statements is not full, it is suitable for wide usage by the system of companies' management.

Particular attention should be paid to accounting objects measurement in the process of accounting statement. It is necessary to consider the presence of interrelation between property measurement and financial results of the company activities. For instance, increasing value of property, because of using the chosen method of its measurement on the date of statement accomplishment determines companies' increasing potential profits of additional capital. In the contrary, decreasing value of property because of its overestimation on the date of statement accomplishment causes decrease of the company's profits.

Nevertheless, mentioned circumstances do not anyhow influence the validity and informational effectiveness of property appraisals. In this aspect, we should consider the position by V. Palii who suggests conducting reassess of particular assets according to the changes of prices on them for reflection in the statement on the reporting date in order to express in the real terms the value of capital used or value of property, which is renewed through amortization. [6, p. 102].

Renewal value for statement measurement of the assets has to be accepted regardless the market prices being increased or decreased relatively to actual cost of the assets, which had been earlier fixed in the statement or earlier accepted measurement on renewal value. Differences appearing in value of current assets have to be taken to costs and incomes of the reporting period, and for the assets of long-term use directly to change of equity basis.

While preparing the accounting information in the aspect of accounting objects, anticipative demands of users should be considered. Anticipation is prediction of possible course of events, premature coming of a particular phenomenon. It is considered as the way to balance property value and capital rates of economic players. The example of using anticipation of capital reserves formation in accounting. Preconditions for using anticipation are:

- Economic load of accounting objects which are considered in the aspect of anticipation;

- Calculation the possibility of value verification of accounting objects in terms of definite quantity range;

- Possibility of following the imparity principle and reflection of the articles on financial statement;

- Anticipation suitability, which stipulates the possibility of actions like reservation in order to form accounting information for the wide range of users.

In the international practice for preparation the financial statement, there is a widely used principle of "fictitious liquidation". The result of using the principle of fictitious liquidation is accomplishment of financial statement based on the null-balance mechanism. Let us consider the brief essence of the principle. For accounting information creation in periodically fixed time intervals inventory of the assets is conducted, in the process of which they are measured in consideration with a view that they might be sold in free conditions. Value of accounts payable is subtracted from the obtained value. The result is accepted as the value of pure assets, which in its turn can be compared to the correspondent value of the pure assets of the previous periods. Therefore, the dynamics of pure assets value and the results of management 
work are estimated. Moreover, obtained value of pure assets is used for calculation the index of global financial effectiveness (profitableness) which is obtained as the difference between pure assets at the beginning and the end of the period excluding in-house consuming by founders and shareholders. Accounting information prepared with following the principle of "fictitious liquidation" can be used while making tactic decisions and estimation of economic activity as it allows definition of the company profitableness. Furthermore, this information allows modeling economical processes and situation, which can appear in definite economic conditions.

That is why this principle is suitable and can be used with the aim of informational support of the management system in the process of cash flows management, profitability, financial results and property as its implementation provides opportunity to produce business plans for such directions of management realization, obtain market figures characterizing ownership, profitableness and financial flows, develop and implement correspondent management decisions. One more approach to preparation of financial statement is informing users about the results of financial activities following the principles of organic balance theory, offered in 1921 by German professor of economy F. Schmidt [7], who set up examination of annual financial statement in general economical position, as he explored every single economic unit as a cell "in the body of economy".

According to the principles of the organic balance theory, positive result of economy is discussed only providing that a company has fixed its position in the market. In other words, in case of increasing prices on property being in disposal of the enterprise the past of its profit should be used for its potential on the previous level maintenance. If price increase is not considered, obtained profit will partly include fictitious profit determined by inflation. This fictitious profit, as F. Schmidt emphasizes, should be reflected in the statement separately from the real one, obtained from economic activity of the company.

Following the principles of organic balance theory is objectively essential in preparation of financial statement in the aspect of determination of reproductive cost of accounting objects.

Therefore, implementation suitability of explored principles and approaches to financial statement preparation is determined by its purpose, sphere of application and users' system of targets according to which particular statements are completed.

It should be noted that using fair value in financial statement accomplishment is used in global accounting today. The important stage of development of fair value conception can be observed in 2006 in issue of American Standard SFAS 157 "Fair Value Measurement" and acceptation of the International Standard IFRS-13 "Fair Value Measurement" in June 2011. Identical title in not a coincidence as IFRS-13 was the result of cooperation of International Accounting Standard Board and Financial Accounting Standards Board of the USA.

Fair value measurement is not a principally new phenomenon in accounting. Analyzing history of foundation of the fair value conception, the significant periods of its development should be marked.

The first period lasting from 1850 s to 1970 s characterized by coexistence of historic and fair value with domination of accounting on primary value and finished with issuing legislative acts fixing historic value as the united base of the measurement.

The second period from 1970 to 1990 s containing theoretic search for the united conception of accounting, revealed disadvantages of historic value measurement and created the basis for formation of the modern fair value conception.

The period from 1990s to 2005 is characterized with international and inter-professional convergence in the sphere of measurement in accounting as well as significant extension of fair value implementation. Eventually, the modern stage of accounting on fair value is determined with development of the united management of assets and liabilities fair value measurement. Nowadays approbation of the conception in practice can be observed.

\section{Fair Value Measurement Development}

An enterprise, on the one hand, is the subject that is the participant of market relations. Evidence of this is in its accomplishment of buying and selling functions. On the other hand, an enterprise can be also an object of market relations as it has value and can be sold that is it becomes a kind of goods that determines necessity of its value measurement. Therefore, an enterprise can be given the characteristics of the goods. Firstly, an enterprise is the production goods, investments realized with the aim of obtaining profit in future. Secondly, an enterprise is a system, complexity and structure of which define the possibility of selling-buying both the whole system and its particular elements. Thirdly, enterprise value dynamically changes as it depends on the influence of external and internal factors.

Therefore, it is possible to suppose that enterprise value as well as any other goods is accounting unit of its exchange economic value. In its turn, the index of exchange economic value of an enterprise is the result of the index of its general economic value capitalization [8]. As opposed to value, price of an enterprise is an actual contractual sum of money in one-time or stage-by-stage way paid by a buyer to buy it out from the previous owner, including the state [8].

That is why enterprise value is an integral characteristic, which, on the one hand is the vector of its stable development, while on the other hand is the ability to generate values for different groups of economic players. Therefore, in modern accounting in the aspect of market relations an enterprise should be assessed not only on its property value at the particular moment but also in the aspect of enterprise value as goods object.

That is why the accounting concept of "value" cannot be observed only as the way of value measurement, it should be explored as the element of the accounting method, which expresses the value of measurement the objects, processes and phenomena of activities by economic players in money terms 
or the opinion about the object value which is accomplished by the measurement subject according to the appropriate privileges and competence level.

In the global practice today, the priority direction of development of enterprise's assets and liabilities measurement is the fair value conception, which in the stead of historic value measurement.

Fair value is a market measurement, not the measurement considering specificity of the economic player. For other assets and liabilities, there might be no market information of market operations information on which is disclosed. However, the aim of fair value measurement in both cases is the same - to define the price on which common operation of assets selling or liabilities transfer could be implemented between market makers on the date of measurement in existing market conditions (that is original price on the date of measurement from the point of view of a market maker which hold the asset or liability) [9].

"Fair value is not a parameter specific for a particular company providing financial statement as well as it does not consider a particular market maker whose risk or particular assessment or synergetic effects can differ from the measurements of other market makers. The company, which provides the financial statement, should consider the factors, which market makers would consider in general. Fair value should not be measured on the grounds of particular market maker suggestions of intentions on using the considered asset of liability. Fair value should represent the price which common market makers are ready to pay for the asset" [10].

Discussing the role of fair value in accounting statement, it should be noted that assets and liabilities measurement on fair value allows formation of financial statement according to the interests of its users. In developed market economy, financial statement of companies is a way of communication between the company and interested users. In such function, financial statement should provide the information, which could be useful to existing and potential investors and creditors as well as other users in making rational decisions on investments, crediting etc.

It is important to note that acceptation of SFAS 157 "Fair Value Measurement" caused a lot of confusion with the procedure of using fair value in accounting, methodology of definition and measurement of particular assets and liabilities, especially in the field of banking financial statement. Besides, during 2008-2009 a lot of analysts, experts supposed this normative document to be one of the reasons of financial crisis in the country.

Usage of the "fair value" concept was started even before the global financial crisis at the beginning of 1990s. SFAS 157 contained some additions to already existing standards. "Before issuing this document, there were different definitions of fair value and limited instructions on using these definitions by GAAP. Besides, these instructions were dispersed in plenty of international standards of financial statement, which demand fair value. These differences created incompatibility, which made implementation of GAAP more complicated. While development of this document, the Board considered the necessity of increasing coordination and comparability in fair value and extension of the scale of information disclosure about fair value» [11].

Major peculiarity of SFAS 157 comparing to other standards: asset price should be determined by its exit price, with the methods of the price definition are given, and it is forbidden to use the entry price of the assets. Before this standard, methods of fair value definition had not been clearly described, that is why issue of this standard was timely and taken in the interests of investors.

During 2008-2009, FASB had been creating work groups dealing with settling contradictory problems, bringing forward to discussion the content of instructions developed to improve the practice of accounting practice on fair value. It should be noted that one of the reasons to publish IFRS 13 was the wish to stop existing contradictions in the different standards by IFRS, as well as differences between IFRS and GAAP US. Cooperative investigations and consultations resulted in issuing IFRS-13 and correction of some positions in SFAS 157 that allowed providing the united definition of fair value, conceptual basis of fair value measurement, united requirements to information provision.

All this proves that global society makes considerable steps to pass to extensive implementation of fair value in financial statement, as theoretically this measurement is recognized as the most presentable and the best in reflection of real value of assets and liabilities of an enterprise.

There are some differences in the procedure of accounting fair value according to these two standards exist. In fair value measurement of investments into investment companies, US GAAP contain practical instructions that allows to use data about pure value of the assets, investments into investment company as measured on fair value providing the correspondence to particular requirements, while in IFRS 13 such practical instructions are absent.

Fair value measurement of financial liabilities on demand of which US GAAP defines that fair value is measured as the sum, which has to be paid on demand on the reporting date. Meanwhile, according to IFRS 13 fair value measurement of financial liabilities on demand could not be less than current cost of the sum before payment on demand. In the aspect of information disclosure IFRS 13 requires quantitative analysis for financial instruments, which are measured on fair value and classified in terms of three-level hierarchy of the fair value sources, while US GAAP do not include the same requirements. Meanwhile, SFAS 157 (today chapter 820) includes different requirements on the information disclosure to non-public companies. These days many scientists, accountants, financial managers of many countries continue debating on accepted standards on implementation of fair value.

O. Georgiou and L. Jack suppose that definition of fair value is often a key problem for practitioners while conception of fair value is also doubtful in the aspect of its theoretical rationality. In the context of the recent credit crisis, accounting on fair value and fair measurement brought forward a number of critical statements, particularly from financial institutions. 
Although the concept of «fair value» in court trials today becomes one of the reasons of the financial crisis, the major questions which we should try hard to answer is if accounting on fair value really provides more useful information for investors than alternative approaches to accounting. Our investigation of the issue provides the positive answer, which mostly depends on the quality of measurement fair value and importance of its further documentation [12].

Analysis of accounting requirements to using fair value in accomplishment of financial statement (Table 1) shows that today most countries oblige banks, financial and crediting institutions to accomplish financial statement basing on this particular measurement.

Table 1. The list of countries, which use fair value in financial statement accomplishment

\begin{tabular}{llll}
\hline Domestic unlisted companies & Allowed to all the enterprises & Is obligatory for all the enterprises & Is obligatory for particular enterprises \\
\hline Albania & & + & + \\
Armenia & & & + \\
Austria & & & + \\
Azerbaijan & & + & + \\
Belgium & + & & \\
Belarus & + & & + \\
Cyprus & & & \\
Denmark & + & & \\
Germany & + & & + \\
Greece & + & & + \\
Ireland & & & + \\
Israel & + & & + \\
Italy & & & + \\
Kazakhstan & & + \\
Moldova & & + \\
Poland & & + \\
Romania & & \\
Serbia & & \\
Slovenia & & + \\
USA & & \\
Turkey & & \\
Ukraine & & & + \\
\hline
\end{tabular}

\section{Normative Regulations of Using Fair Value Measurement in Ukraine}

First of all, let us define the levels of normative provision of domestic financial statement accomplishment by the enterprises excluding budget institutions (hereinafter enterprises). Normative provision of domestic financial statement accomplishment by Ukrainian enterprises includes:

1) on the legislative level - the Law of Ukraine "About accounting and financial statement in Ukraine" [13];

2) on the normative level - Regulations on Standards of Accounting (RSA), other normative-legislative acts about accomplishment of financial statement, approved by the Ministry of Finance of Ukraine [14];

3 ) on the recommendation level - methodical recommendations on implementation of Regulations on Standards of Accounting developed on the basis of Regulations on Standards of Accounting correspondently to branch peculiarities by ministries, other central bodies of executive power in terms of their competence.

In Ukraine the influence of accounting on fair value is increasing.

Definition of fair value in Ukrainian accounting was corrected on 2013, it is provided in RSA 7 "Basic means" and RSA 19 "Enterprises uniting" according to which fair value is the sum on which it is possible to sell the assets of pay for liabilities in common conditions on the particular date.
Obviously, these corrections were made due to appearance of IFRS 13. According to IFRS 13 «fair value» is the price which could be obtained for selling an asset of paid for transfer of a liability in a common operation between market makers on the date of measurement?

Besides, the standard gives clear definition of a "common operation" is an operation which stipulates disclosed offer on the market during the period of measurement date for accomplishment of marketing activity which is usual and common for the operations with such assets and liabilities [9].

Considering the definition "fair value» in Ukrainian legislation, it is not clear how to determine fair value because standards do not decode the definition of "common conditions". Besides, many questions appear for accountants and scientists while defining fair value of biological assets. Usage of fair value is not usually accomplished on enterprises.

The reasons lie in a number of circumstances:

(1) Instability of state policy on formation of state buying prices for agricultural products;

(2) Inaccessibility of information about value of biological assets and agricultural products on the market of assets;

(3) Absence of methodical provision of the mechanism of fair value formation for the given objects of accounting;

(4) Limited access of agricultural enterprises to stock market of agricultural products that restricts information about market prices based on which fair 
price should be formed.

Using fair value in Ukrainian accounting is multiply observed in current Regulations on Standards of Accounting (RSA). Table 2 shows the list of RSA, which stipulate the necessity of fair value implementation while accounting.

Comparing the sphere of implementation of fair value with IFRS (Table 3), it is similar a lot to the requirements of implementation in RSA.

\section{Table 2. List of FSA which stipulate the necessity of fair value implementation}

\begin{tabular}{ll}
\hline Standard name & Scope \\
\hline & - initial value of basic means which are obtained free of charge formation; included into statutory capital of the \\
& enterprise; obtained in the exchange of the similar (not similar) objects; \\
& - fair value is used only in reassessment of basic means; \\
RSA 7 "Basic means" & - initial value as a result of income formation: exchanging intangible assets obtained as a result of exchange on the \\
& similar (not similar) object; obtained free of charge; included into statutory capital of the enterprise; obtained as a \\
& result of enterprising uniting. \\
& - reassessment of intangible assets \\
& - initial values of the stocks included into statutory capital of the enterprise formation, obtained free of charge; \\
RSA 7 "Intangible assets" & obtained in the exchange of the similar (not similar) stocks; \\
RSA 9 "Stocks" & - recognition of cost price of financial investments obtained through exchange on securities of own emission; \\
& - procedure of recognition of cost price of financial investments on the date of statement; \\
RSA 12 "Financial investments" & - during recognition of value of financial instruments (as a result of exchange, realization etc.) \\
& - during measurement of financial instruments; \\
RSA 13 "Financial instruments" & - during accounting hedging. \\
& - accounting during financial renting \\
RSA 14 "Renting" & - while measurement of income \\
RSA 15 "Income" & - definition of fair value of obtained, indentified assets and liabilities \\
RSA 10 "Enterprises uniting" & - the procedure of correction of statement figures; \\
RSA 22 "Inflation influence" & - initial value while incoming both free of charge and obtained as the contribution into statutory capital formation; \\
RSA 30 "Biological assets" & - formation of initial value of additional biological assets. \\
RSA 32 "Investment real estate" & - reflection of investment real estate in financial statement \\
RSA 34 "Payment basis" & - recognition and measurement of operations payments on which are done on the basis of shares \\
\hline
\end{tabular}

Table 3. Sphere of implementation of fair value y IFRS

\begin{tabular}{ll}
\hline Standard name & Scope \\
\hline IFRS 3 "Business Combinations" & $\begin{array}{l}\text { Bought assets, liabilities, uncontrolled shares of ownership, } \\
\text { conditional obligations while the business uniting } \\
\text { assets, held for selling } \\
\text { financial instruments, measured on fair value at initial } \\
\text { IFRS } 5 \text { "Non-current Assets Held for Sale and Discontinued Operations" } \\
\text { IAS } 32 \text { "Financial Instruments: Presentation" }\end{array}$ \\
IAS 39 "Finansial Instruments: Recognition and Measurement" & $\begin{array}{l}\text { costs of outcoming; } \\
\text { costed value of assets, measured as fair value minus } \\
\text { IAS } 36 \text { "Impairment of Assets" }\end{array}$ \\
IAS 38 "Intangible Assets" & $\begin{array}{l}\text { of outcoming } \\
\text { assets of pension plans } \\
\text { non-money governmental grants; }\end{array}$ \\
IAS 19 "Employee Benefits" & $\begin{array}{l}\text { investment property } \\
\text { biological assets; agricultural products in the period of }\end{array}$ \\
IAS 40 "Investment Property" & harvesting. \\
\hline
\end{tabular}

One more reason of fair value implementation is peculiarities of Ukrainian business culture. For Ukrainian accountant it might not be "fair" if something, firstly, contradicts with the law, and secondly, is not proved by initial (historical) accounting. Few accountants are now thinking of reflection of real value of the enterprise in the financial statement. Besides, in terms of taxes legislation complexity, constant control from fiscal authorities, most companies are interested in taxes accounting and put their accounting closer to following these particular requirements.

While legislative changes for regulation of fair value accomplishment of financial statement according to domestic standards have not been implemented, alternative decision of using fair value for reflection real value of assets and liabilities is using IFRS.

\section{Algorithm of Using the Form of Accounting with Fair Value Implementation}

Process of financial statement accomplishment on fair value implementation should be started from determination of the form of the accounting: parallel accounting or transformation of financial statement. Figure 1 shows the criteria of such choice:

Depending on the chosen type of accounting, an enterprise conducts reformation of the system of accounting. In parallel accounting it is advisable: (1) change of accounting ideology; (2) review of the norms of accounting policy of the enterprise; (3) change of working Plan of accounts; (4) new organization 
of analytical accounting; (5) separation of management and tax accounting into particular subsystems; (6) change of movement of information flows and analytical processing of the information.

While transformation of financial statement the following actions should be provided:

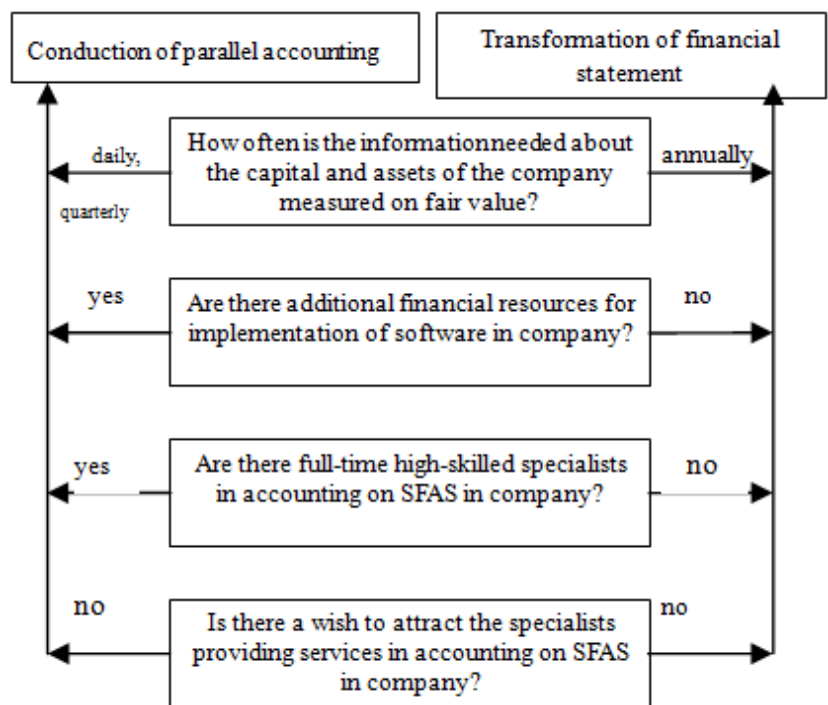

Figure 1. Algorithm of using the form of accounting based on fair value

(1) carrying out the analysis of used accounting policy and state of accounting;

(2) analysis of the level of using fair value measurement in the company;

(3) analysis of the accounts of turnover balance and preparation of operational documents on which the fair value measurement could be formed;

(4) completion and coordination of corrective and reclassifying posting;

(5) input of corrective posting;

(6) preparation of operational tables for accomplishment of financial statement according to IFRS;

(7) forms of financial statement preparation.

The result of using fair value for accomplishment of financial statement will be:

(1) obtaining accounting, allowing provision of actual and credible information about the company value to internal and external users of the financial statement;

(2) opportunity for the company to go out to the international investment market;

(3) opportunity to make management decisions based on real financial condition of the company.

\section{Conclusions}

In general, in the context of chaotic economic environment, using fair value as a measurement will allow the provision of statements' major function - giving credible information on the particular date. Conception of accounting on fair value in global practice today is a priority direction in development of measurement while accomplishment of financial statement.
Global society makes significant steps to approach to general implementation of fair value into financial statement one of the proofs is publication of IFRS 13, in which existing contradictions were eliminated for different standards of IFRS, as well as considerable differences between IFRS and GAAP US.

Most countries in the world today oblige banks, financial and crediting institutions to accomplish financial statement basing on this particular fair measurement.

Although Ukraine is seeking for approximation of domestic accounting to the requirements of IFRS, the concept of «fair value» in Ukrainian accounting standards is still unclear and non-understandable for usage. While of financial statement using fair value, it is necessary to use the requirements of IFRS 13, considering, firstly, accounting forms (parallel or transformation of statement) and secondly, consider corresponding peculiarities of implementation for each of the approaches.

\section{References}

[1] C. Bonaci, J. Strouhal and V. Razvan "Fair Value Approach: Recent Developments and Professionals' Perceptions," WSEAS TRANSACTIONS on BUSINESS and ECONOMICS, vol. 10, pp. 180-189, July 2013.

[2] IFRS USA, Is IFRS coming to America?, 2012, retrieved from: http://ifrsusa.wordpress.com/

[3] S. Kuznetsova and A. Kuznetsov "The Information Perspective of Management Accounting in Ukraine: The Synergistic Approach and Arrow's Impossibility Theorem," in World Journal of Social Sciences Vol. 4. No. 1. March 2014 Issue. pp. $140-153$.

[4] Bodie Z. Finance. The tutorial.. / Z. Bodie, P. Merton; [trans. From English.]. - M.: Publishing research house "Williams», 2000. $-592 \mathrm{p}$.

[5] Burton John C. Handbook of accounting and auditing./ John C. Burton, Russell E. Palmer, Robert S. Kay. - Boston. New York: Warren, Gorham\& Lamont, 1981. - 1800 p.

[6] V. Palii. Century Problematic issues of asset valuation and the circumstances in IAS / V. Palii // Formation of a market economy in Ukraine. Scientific collection: special edition 7. Financial analytical tools reforming the economic system of Ukraine. - Lviv: Nsereko, 2001. - pp. 99-104.

[7] Scmidt F. Die organische Bilanz im Rahmen der Wirtschaft./ F. Scmidt. - Leipzig, 1921.

[8] L. D. Revutsky. Fundamental value, Foundation-supplemented flax cost and fair value of the enterprise: concepts, indicators and methods of their determination. - M.: // Evaluation questions, № 3, 2012. pp 35 - 44.

[9] International standards financial integration: [Electronic resource]. $\quad-\quad$ Mode of access: http://www.ifrs.org/Pages/default.aspx

[10] New IFRS consolidation and fair value measurement [The staff of authors Ernst \& Young]. Moscow: Alpina Publisher 2014.$406 \mathrm{p}$. 
[11] US GAAP : [Electronic resource]. - Mode of access: http://www.fasb.org/st/

[12] O. Georgiou, L. Jack. In pursuit of legitimacy: A history behind fair value accounting, The British Accounting Review, Vol. 43, 2011, pp. 311-323
[13] The Law of Ukraine "On accounting and financial reporting in Ukraine":[Electronic resource]. - Mode of access: // http://www.rada.gov.ua/

[14] Regulations (standards) of accounting: [Electronic resource]. Mode of access: // http://www.rada.gov.ua/. 